Article

\title{
A Survey on User Acceptance of Wireless Electric Vehicle Charging
}

\author{
Daniel Fett *, Axel Ensslen ${ }^{(1)}$, Patrick Jochem and Wolf Fichtner \\ Institute for Industrial Production (IIP), Karlsruhe Institute of Technology (KIT), Hertzstr. 16, \\ 76187 Karlsruhe, Germany; axel.ensslen@kit.edu (A.E.); jochem@kit.edu (P.J.); wolf.fichtner@kit.edu (W.F.) \\ * Correspondence: daniel.fett@kit.edu
}

Received: 8 May 2018; Accepted: 18 August 2018; Published: 22 August 2018

\begin{abstract}
This study presents results of a survey-based analysis on user acceptance of wireless electric vehicle charging. A structural equation model is developed based on Davis' technology acceptance model (TAM). It is expanded integrating elements of Ajzen's theory of planned behavior (TPB). The main factors influencing acceptance of wireless electric vehicle charging are evaluated and analyzed. Empirical findings indicate that survey participants' acceptance of wireless electric vehicle charging is mainly influenced by affective evaluations of wireless charging, subjective norms, perceived usefulness of wireless charging, and environmental awareness. The results indicate a high degree of acceptance for wireless charging. Even individuals with lower degrees of acceptance are willing to use wireless charging within car-sharing or commercial fleets.
\end{abstract}

Keywords: wireless charging; user behavior; inductive charger; battery charge; EVSE (Electric Vehicle Supply Equipment)

\section{Introduction}

According to the German Climate Action Programme 2020 the transport sector is supposed to contribute to the 2020 climate targets even though its contribution is missing so far [1]. One of the measures to achieve this goal is to increase the share of electric vehicles (EV). Accordingly, in 2014 the German government confirmed the ambitious target of one million EVs in 2020 and six million EVs in 2030 [2]. Additionally, several German cities are having difficulties meeting the thresholds for particulate matter and nitrogen oxide emissions required by the European Commission and are therefore discussing partial driving bans for vehicles with combustion engines [3]. The German government decided to subsidize EVs registered after May 2016 with up to 4000 Euros [4]. However only 11,652 buyers (20,627 including plug-in hybrid electric vehicles) applied for this subsidy until May 2017 [5], increasing the total number of EVs to 42,015 [6,7]. Even Chancellor Merkel doubts that German EV targets for 2020 will be reached [8]. Besides other reasons like limited range and high purchase prices [9], the lack of comfortable charging options might be a reason for still low adoption rates [10]. According to the former head of AUDI's technical development division Mr. Hackenberg “... plug-in hybrids and electric cars will never reach their full market potential unless wireless inductive charging spreads across the fleet" [11]. Surveys conducted by the National Renewable Energy Laboratory seem to support this statement [12]. German car manufacturers are offering first wireless charging solutions [13-15]. Advantages are that no cable is needed and that users do not have to plug in a cable [16]. Consequently, mechanical wear is low and resistance to weather and vandalism is high [16]. Inductive charging systems are particularly advantageous in bad weather situations as users do not get dirty hands [17]. Wireless charging seems to have safety advantages due to its potential-free design which is protected against contact by shielding [16]. However, electromagnetic radiation might be disadvantageous for acceptance [16]. Further major advantages of wireless charging 
are its ease of use, its convenience and that it is more innovative [18]. It seems to be more important for German plug-in hybrid EV users than for zero emission EV users [19]. However, wireless charging comes along with a higher energy consumption $[16,20]$. Willingness of potential users to accept additional costs for inductive charging is related to perceived benefits or disadvantages arising from its use [16]. Interest in dynamic wireless charging is high [18,21]. However, due to uncertainties concerning economic viability of dynamic wireless charging systems, particularly concerning high economies of scale necessary [22,23], the focus in this article is on stationary inductive charging.

Affective, cognitive, and conative dimensions of wireless EV charging were evaluated by analyzing EV driver's charging process acceptance in a lab experiment with 60 participants [10]. Results indicate comparably high acceptance levels of inductive charging supported by the magnetic pulse positioning system technology what might increase overall acceptance of EVs [10].

However, to our knowledge, the main factors influencing acceptance of wireless EV charging have not been analyzed with the help of regression or structural equation models (SEM) so far. This article intends to fill this gap in literature by analyzing factors potentially influencing acceptance of wireless EV charging. Additionally, differences between commercial (fleet) users and private users, as well as between individuals who regularly use EVs and those who do not, are examined.

This paper is structured as follows. In Section 2 the methodology and the empirical data used to evaluate the structural equation model are described. Section 3 shows results concerning acceptance of wireless EV charging, quality measures, main effects of the SEM, as well as findings of the multigroup analyses. In Section 4 potential limitations of the work are discussed, before conclusions are provided in Section 5.

\section{Methodology and Data}

\subsection{Structural Equation Modelling}

The model is mainly based on [24,25], where two models explaining user acceptance of EVs are introduced. The models are based on the technology acceptance model originally developed by Davis [26]. The model is extended using elements of a past paper [27], where a model for user acceptance of driver assistance systems based on the theory of planned behavior by Ajzen is presented [28]. The complete structural model depicting the hypotheses is shown in Figure 1.

The latent variables and their definitions are presented in Table A1 in the Appendix A. In accordance with another past paper [29], mainly reflective constructs are used in order to represent the latent variables. However, for some latent variables, such as comfort, it is necessary to consider different aspects (e.g., the need to park more accurately and not having to handle a potentially dirty power cable), which as a whole form the construct. Hence, these constructs are specified as formative. A questionnaire was created to measure the constructs with items derived from different studies, majorly from two past papers [24,30]. The detailed measurement models for all constructs and their abbreviations are described in Table A2 in the Appendix A. Details on the survey data used is provided in Section 2.2. A partial least squares structural equation model (PLS-SEM) was chosen, as is recommended for model extensions and exploratory research [31]. In general, the quality of results from covariance-based SEM and variance-based SEM like PLS-SEM used in this study are comparable [32,33]. The validity of this approach is discussed in Section 3.2. 


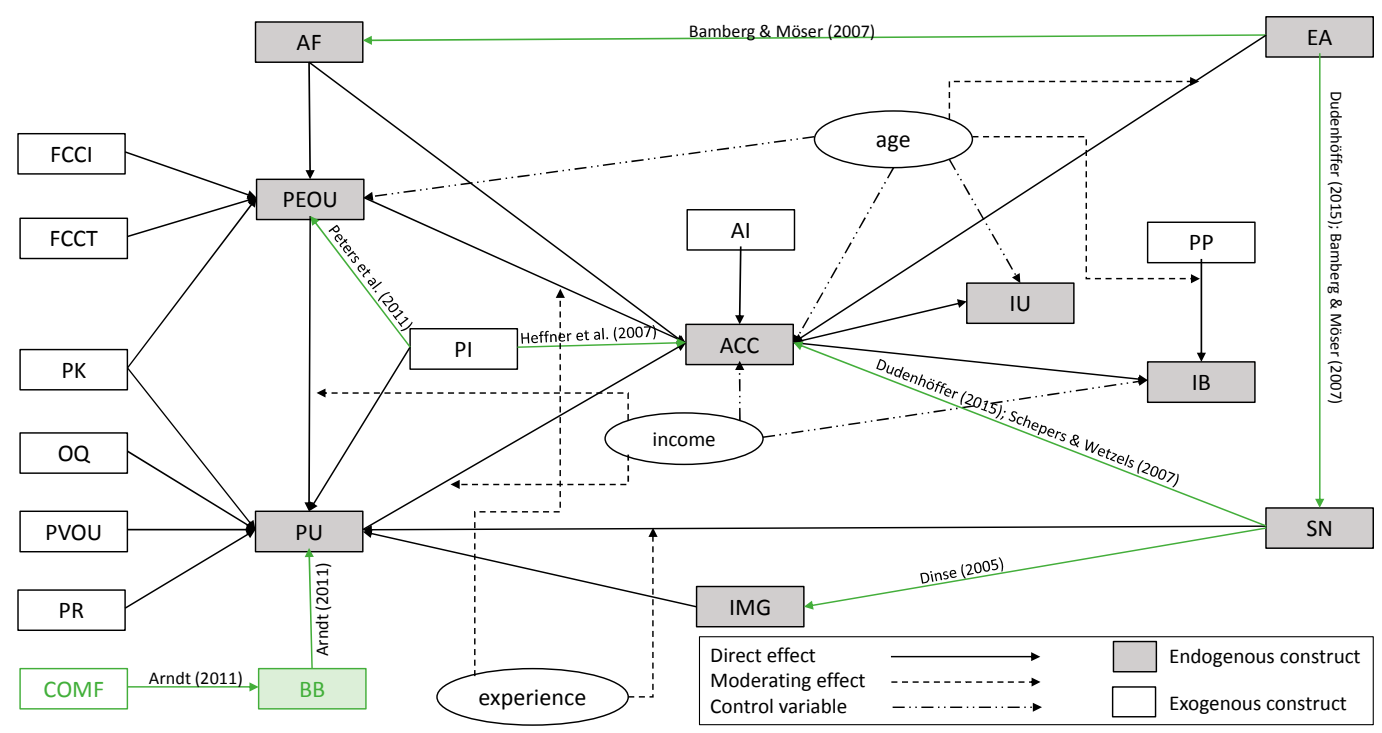

Figure 1. Structural equation model. ACC: Acceptance; AF: Affect; AI: Automotive involvement; BB: Behavioral beliefs; COMF: Comfort; EA: Environmental awareness; FCCI: Facilitating conditions charging infrastructure; FCCT: Facilitating conditions charging time; IB: Intention to buy; IMG: Image; IU: Intention to use; OQ: Output quality; PEOU: Perceived ease of use; PI: Personal innovativeness; PK: Perceived knowledge; PP: Price perception; PR: Perceived risk; PU: Perceived usefulness; PVOU: Perceived visibility of use; SN: Subjective Norm [34-38].

\subsection{Survey Data}

After pretesting, empirical data to validate the SEM was collected. An online survey was carried out between December 2015 and January 2016. 435 respondents started the survey, 266 individuals finished. Two responses contained the same value for all answers and were therefore removed. Additionally eight responses were removed due to more than $15 \%$ missing values [27], another six responses because of too short answering times (faster than $7 \mathrm{~m} 57 \mathrm{~s}$ equaling half the median response time) [39]. According to the "ten times rule" a minimum sample of 90 is required for the presented model [33]. Therefore, the sample size is sufficient. The total of 250 valid records consists of 137 records of survey participants that were recruited in various car or electric mobility related internet forums and 113 records from participants of the Get eReady research project carried out in south-western Germany between 2013 and 2016 [40]. The participants of the Get eReady project were fleet users and fleet managers of organizations (e.g., companies, public authorities, or associations) using EVs.

The sample is not representative of the German population as only $6 \%$ of the respondents are female. On average the sample's respondents are 42.6 years old, one third $(30.3 \%)$ are between 40 and 49 , and $76 \%$ are between 30 and 59 years old. The household incomes per month are comparably high with $32.9 \%$ ranging between $3000 €$ and $5000 €$ and $49.4 \%$ being above $5000 €$. Potential explanations for that are twofold: first, the share of people living in multiperson households is very high $(82.4 \%)$. Second, education levels are very high as well with $54.5 \%$ of the respondents having at least a bachelor degree. Most respondents are experienced EV users. Only 9\% have never driven an EV. More than two thirds use EVs at least once a month, 58\% even more than once a week. Figure 2 summarizes demographic information and EV experience levels of the respondents. Lots of similarities to [19] a large past study on early EV adopters in Germany can be observed. In this study most of the participants were also males $(89 \%)$, had a university degree $(50 \%)$, lived in multiperson households $(89 \%)$. and had above average incomes. 

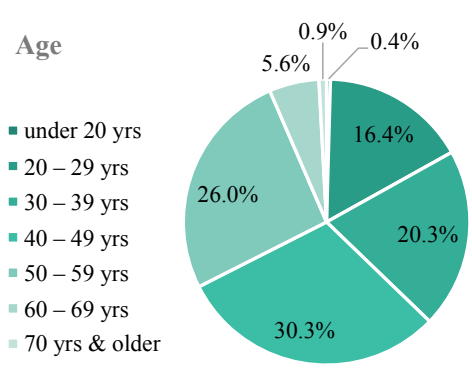

- PhD or higher

- university diploma, master

- bachelor, BA

- master craftsman

- university entrance diploma

" apprenticeship

- secondary education

no formal education

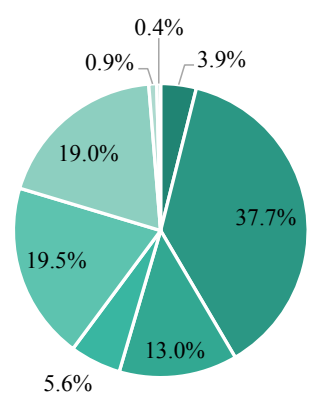

Usage frequency

- (almost) every day

- 1-3 days per week

- 1-3 days per month

- less than 1 day per month

- former user

- only test drives/passenger

never

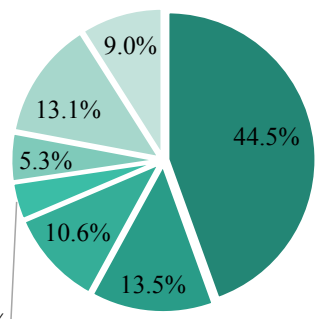

Figure 2. Demographics and EV experience of the sample.

\section{Evaluation}

\subsection{Acceptance}

Figure 3 shows average scores of the latent variable acceptance and its indicators. A Likert scale ranging from 1 ("completely disagree") to 6 ("completely agree") was used to measure all indicators. Values of 4 and higher are regarded as consent (positive values), values of 3 and lower as dissent (negative values). About two thirds of the respondents would generally like to have a wireless charger in their vehicle and would prefer wireless charging over wired charging (scores of 4 and higher). With scores of 5 or 6 , the majority even has a strong consent to those two indicators. Even though more than half of the survey participants would recommend wireless charging to their friends, the average value for this indicator is only weakly positive (3.75). More than $40 \%$ stated that wireless charging increases their interest to use and buy EVs. However, the average values are weakly negative ( 3.26 and 3.14). This might be due to the high share of respondents with high EV experience levels. EV users already have a high interest in EVs that is not increased by wireless charging. The resulting construct value for acceptance is weakly positive with an average of 3.71 . For the majority of respondents the average value of acceptance reaches scores of four and higher.

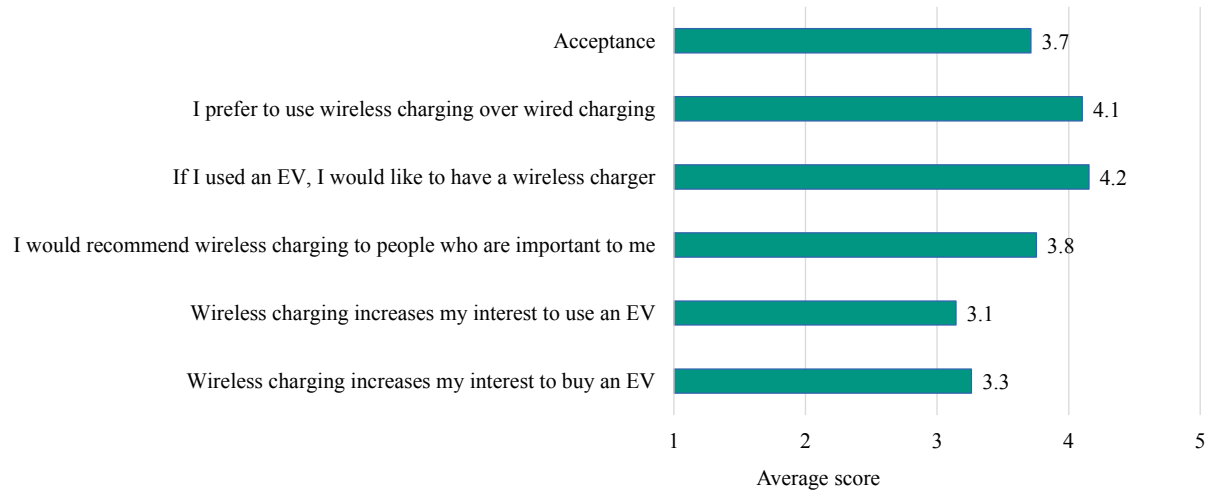

Figure 3. Average values of the construct "acceptance" and its indicators. 
In addition to acceptance, the intention to buy a wireless charger and to use wireless charging offered in fleet cars was analyzed. Sixty-three percent of the survey participants stated that they would be willing to buy a wireless charger, if they buy a new EV (scores of 4 and higher). For leasing the share is $7.2 \%$ lower. The average values are only weakly positive, almost neutral, with 3.77 and 3.62. About $46 \%$ of the respondents are generally willing to pay premiums for wireless charging, on average 3.14. The resulting average of the construct "intention to buy" is neutral with 3.52. Willingness to use wireless charging offered in fleet cars is much higher. More than $80 \%$ of the persons stated that they could imagine using wireless charging in car sharing vehicles, and $85 \%$ stated that they would at least try it. Averages are 4.80 and 4.53. The resulting construct value for "intention to use" is 4.67.

\subsection{Quality Criteria of PLS-SEM Modeling Activities}

All reflective measurement models are tested on reliability and validity. To assure indicator reliability the factor loadings $(\geq 0.4)$, the significance levels $(t \geq 1.6)$ and the item-to-total-correlations $(\geq 0.4)$ are analyzed [41-43]. Construct reliability is tested by Cronbach's alpha $(\geq 0.65)$, factor reliability $(\geq 0.6)$ and average variance extracted $(\geq 0.5)$ [44-46]. Convergence validity is automatically given, if the average variance extracted and the factor reliability are above the thresholds for all constructs [47]. The Fornell-Larcker criterion is met for all constructs, ensuring discriminant validity [46]. As correlations between indicators of formative measurement models are not necessary, statistical quality assessment as for reflective measurement models cannot be applied [47]. Some authors even state that it is not possible at all to test them for reliability and validity $[29,48]$. Nevertheless, formative measurements were chosen for the five constructs shown in Table A2 in the Appendix A. Reflective measurement models would not have been able to cover all necessary aspects of the constructs. Meta-analyses support the decision to use formative constructs. They have shown that up to $35.2 \%$ of measurement models in peer reviewed articles are erroneously specified as reflective [49-51]. As statistical quality assessment is not possible, the C-OAR-SE approach was followed to assure content validity [48]. Additionally, the variance inflation factors $(\leq 5)$ are analyzed to ensure the absence of critical levels of multicollinearity [31].

The $\mathrm{R}^{2}$-value for acceptance is 0.82 . According to literature this is a this is a satisfactory value [52-54]. The predictive value $\mathrm{Q}^{2}$ for acceptance is 0.69 so the model appears to have predictive relevance [55]. According to these scores, the model has a good explanatory value. More details are available in a past paper [56].

\subsection{Main Effects of PLS-SEM}

The results suggest that affect (0.35), subjective norms (0.20), perceived usefulness (0.51), perceived ease of use, and behavioral beliefs (0.12) have significant positive total effects on acceptance of wireless charging. Environmental awareness on the other hand has a significant negative $(-0.29)$ total effect on acceptance resulting from the item on acceptability of increased power consumption of wireless charging being part of the formative construct environmental awareness [56]. Environmental awareness $(-0.07)$, affect $(0.33)$, and perceived usefulness $(0.51)$ have significant direct effects on acceptance. The effects of affect and environmental awareness are amplified by indirect effects. All direct effects are listed in Table A3 in the Appendix A.

Considering indirect effects the model results suggest that environmental awareness has a negative impact on affect $(-0.44)$ and subjective norms $(-0.30)$. The former has a positive influence on perceived ease of use (0.27), which also increases with facilitating conditions charging infrastructure (0.37) and personal innovativeness (0.12). In addition, the model results indicate that comfort has a positive impact on behavioral beliefs (0.66), perceived ease of use (0.19), subjective norms (0.28), and behavioral beliefs (0.23) for their part have positive influences on perceived usefulness. According to the model, all effects mentioned in this section are strongly significant, except for the effect of personal innovativeness on respondents' perceived ease of use, which is only weakly significant. 
Besides the already mentioned endogenous constructs, perceived usefulness is influenced by four exogenous constructs. According to the model results, perceived usefulness decreases significantly with perceived risk $(-0.11)$ and perceived knowledge $(-0.17)$. Output quality $(0.11)$ and perceived visibility of use (0.14) on the other hand have a positive influence on perceived usefulness. These effects are weakly significant respectively significant. Further details concerning the analyses of main effects are available in a past paper [56].

These results are consistent with prior studies showing that willingness to accept wireless charging is related to additional benefits arising from its use [16,17], that its higher energy consumption [20] might be an issue for acceptance [16], and that affect positively correlated with perceived ease of use shows positive effects on acceptance levels [18]. Positive effects of subjective norms are consistent with wireless charging's innovative image [18]. Potential negative effects of safety issues observed in prior studies [16] are consistent with this study's results showing negative effects of perceived risk on perceived usefulness. Beyond these individual criteria and reasons provided, our study explains acceptance of wireless EV charging, i.e., how and with what magnitude latent variables influencing acceptance are interrelated.

\subsection{Multigroup Analyses}

In order to test for moderating effects of different discrete variables the PLS-multigroup analysis as described previously [57] was used. The different user groups in the sample are analyzed distinguishing between private users and commercial (fleet) users as well as between fleet users and fleet managers. Exemplary results include positive effects of perceived visibility of use and perceived ease of use on perceived usefulness, which are only significant for commercial (fleet) users. For private users (weakly) significant positive influences of facilitating conditions charging time on perceived ease of use and of subjective norms on acceptance can be observed. Differences between fleet managers and fleet users include positive impacts of perceived ease of use and personal innovativeness on perceived usefulness, which are only significant for fleet managers. Positive influences of affect on acceptance are also significantly higher for fleet managers. In contrast, negative impacts of perceived risk on perceived usefulness are only (weakly) significant for fleet users. In addition the positive impacts of subjective norm on affect, behavioral beliefs on perceived usefulness, and charging time on perceived ease of use are (weakly) significantly stronger.

The participants are divided into two groups based on the amount of experience (i.e., EV usage frequency) they already had with EVs. Results indicate that experience levels with EVs have various moderating effects. For instance, negative moderating effects are observable on the paths between perceived technological risk and perceived usefulness, environmental awareness and acceptance, as well as between personal innovativeness and perceived ease of use. Survey participants who frequently use EVs and therefore have comparably high experience levels with EV charging are less willing to tolerate the comparably high energy consumption of wireless EV charging. Moreover, EV experience levels have weakly significant positive moderating effects on the relationships between affect and acceptance, subjective norms and image, as well as comfort and behavioral beliefs.

\section{Limitations}

Formative measurement models are used for some constructs (c.f. Section 3.2), whose reliability and validity are hard to confirm by statistical means. As discussed in Section 2.2, the collected survey data stems from early EV adopters. Therefore, the sample is not representative for the German population. Furthermore, most respondents have high experience levels with EVs; for example gender can have a significant influence on the factors influencing EV acceptance [24,25]. It was not possible to test for the effect of gender on acceptance of wireless charging due to the low number of female respondents. Especially taking into account that wireless charging might have the potential to attract new customer groups to EVs and current early adopters are mostly highly-educated males, further studies should try to gather more balanced samples and survey people 
without any EV experience. Since there is only low availability of wireless charging systems in Germany, experience with EVs was used as a proxy. Personal experience has significant influence on EV acceptance $[24,25]$. With increasing availability of wireless chargers, future studies should investigate if personal experience with wireless charging also influences acceptance. The multigroup analyses show significant differences between the factors influencing acceptance of wireless charging. While there seem to be plausible reasons for most of them, these reasons should be confirmed by additional research.

\section{Conclusions and Future Work}

The research presented indicates that in general there is a high level of acceptance for wireless EV charging. Even individuals with lower degrees of acceptance seem to be willing to use wireless charging within car-sharing or commercial fleets. The results suggest that acceptance is higher among commercial customers; especially high for fleet users. According to past studies [30,58], private users and fleet managers who participate in surveys can be characterized as "early adopters" with a high affinity towards electric mobility, while fleet users represent rather "normal users". It could be observed that acceptance of wireless charging and increasing interest in electric mobility caused by wireless charging is highest among "normal users". This might be due to different requirements concerning charging comfort levels of fleet users. In addition, user acceptance of wireless charging and corresponding increasing interest in electric mobility caused by wireless charging is higher amongst users with less EV experience. Interpretation of these findings leads to the conclusion that wireless charging indeed has the potential to increase adoption rates of EVs. Marketing campaigns could particular focus on the fact that wireless charging is useful, which is already the case [13-15]. Additional factors that might be important for the adoption of wireless charging have been derived from the SEM and multigroup analyses results; e.g., the perceived discomfort caused by having to plug-in seems to be smaller for users who already have considerable experience with EVs. According to the results experienced EV users are not willing to tolerate an increase in electricity consumption of $5 \%-6 \%$. Hence, wireless charging systems for this target group need to be particularly efficient. These findings show that EV users' acceptability of wireless charging's higher electricity consumption negatively correlates with the degree of emotional and affective liking of wireless charging (affect), the degree of approval for the use of wireless charging that a person perceives from their social environment (subjective norms), and acceptance. These effects could be particularly focused on when marketing campaigns are designed. Furthermore, for users with only little EV experience the perceived technological risks seem to have a significant negative effect on acceptance. Information on reliability and safety issues, e.g., concerning the shielding from electromagnetic radiation, are very important for potential adopters with rather low EV experience levels. According to the model results for commercial (fleet) users perceived usefulness increases significantly with increasing perceived ease of use. Therefore, a wireless charging system for commercial EV users should be especially user friendly. As EV usage in fleets is particularly promising [59,60], designing wireless charging offerings according to the needs of this target group might be worth considering.

This analysis is based on survey data of EV users with rather high EV experience levels. However, the sample's respondents have not actively experienced wireless charging. As experiencing new technologies might increase corresponding acceptance levels, future work could focus on surveying wireless charging EV users in addition. Wireless charging user needs could then be analyzed in detail. Communication strategies for promoting wireless EV chargers could be developed based on the results of SEM and corresponding multigroup analysis distinguishing between wired charging EV users and wireless charging EV users.

Author Contributions: Conceptualization, D.F., A.E., P.J. and W.F.; Methodology, D.F. and A.E.; Validation, D.F.; Formal Analysis, D.F.; Investigation, D.F.; Resources, D.F.; Writing-Original Draft Preparation, D.F.; Writing-Review \& Editing, D.F., A.E., P.J.; Visualization, D.F.; Supervision, P.J. and W.F.; Project Administration, P.J. and W.F.; Funding Acquisition, P.J. and W.F. 
Funding: This paper has been written in the context of the research projects IILSE and Get eReady. The IILSE project is funded by the German Federal Ministry for Economic Affairs and Energy (BMWi) under the promotion sign 01MX15004. The Get eReady project was funded by the Federal Ministry for Economic Affairs and Energy (BMWi) under the promotion sign 16SBW020E. This publication was written in the framework of the Profilregion Mobilitätssysteme Karlsruhe, which is funded by the Ministry of Science, Research and the Arts in Baden-Württemberg.

Conflicts of Interest: The founding sponsors had no role in the design of the study; in the collection, analyses, or interpretation of data; in the writing of the manuscript, and in the decision to publish the results.

\section{Appendix}

Table A1. Latent variables and their definitions.

\begin{tabular}{|c|c|}
\hline Latent Variable & Definition \\
\hline Automotive involvement & The degree to which a person is interested in cars [25]. \\
\hline Comfort & $\begin{array}{l}\text { The degree to which a person believes that wireless charging increases the comfort of using } \\
\text { electric vehicles [27]. }\end{array}$ \\
\hline Personal innovativeness & The degree of interest in innovations and willingness to try innovative products [62]. \\
\hline Output quality & The degree to which a person believes that wireless charging systems perform well [63]. \\
\hline $\begin{array}{l}\text { Facilitating conditions } \\
\text { charging time }\end{array}$ & $\begin{array}{l}\text { The degree to which a person believes that the use of wireless charging is enabled or hindered by } \\
\text { the charging time }[21,22] \text {. }\end{array}$ \\
\hline $\begin{array}{l}\text { Facilitating conditions } \\
\text { charging infrastructure }\end{array}$ & $\begin{array}{l}\text { The degree to which a person believes that the use of wireless charging is hindered by lacking } \\
\text { infrastructure }[24,64] \text {. }\end{array}$ \\
\hline Environmental awareness & The degree to which a person's decisions are influenced by environmental concerns [67] \\
\hline Behavioral beliefs & The degree to which a person believes that the use of wireless charging will have positive effects [28]. \\
\hline Perceived ease of use & The degree to which a person believes that using wireless charging would be free of effort $[25,26]$. \\
\hline Perceived usefulness & The degree to which a person believes that using wireless charging would be useful $[25,26]$. \\
\hline Perceived risk & The degree to which a person believes that using wireless charging is safe [24]. \\
\hline Perceived knowledge & $\begin{array}{l}\text { The degree to which a person believes to have a broad knowledge about alternative fuel } \\
\text { vehicles [25]. }\end{array}$ \\
\hline
\end{tabular}

Table A2. Overview of measurement models.

\begin{tabular}{llll}
\hline Latent Variable & Composition & \# of Indicators & Source \\
\hline Affect (AF) & Reflective & 3 & {$[24,30]$} \\
Acceptance (ACC) & Reflective & 5 & {$[27,30,68]$} \\
Automotive involvement (AI) & Formative & 3 & {$[25]$} \\
Comfort (COMF) & Formative & 3 & {$[27]$} \\
Personal innovativeness (PI) & Reflective & $5-72]$ \\
Price perception (PP) & Reflective & {$[25,27]$} \\
Output quality (OQ) & Reflective & 3 & {$[24]$} \\
Facilitating conditions charging time (FCCT) & Reflective & {$[24]$} \\
Facilitating conditions charging infrastructure (FCCI) & Formative & 3 & {$[24]$} \\
Subjective norms (SN) & Reflective & {$[24,30]$} \\
Image (IMG) & Reflective & 3 & {$[24,27]$} \\
Environmental awareness (EA) & Formative & 3 & {$[24,73]$} \\
Intention to use (IU) & Reflective & 4 & {$[24]$} \\
Intention to buy (IB) & Reflective & 3 & {$[24]$} \\
Behavioral beliefs (BB) & Reflective & 3 & {$[27]$} \\
Perceived ease of use (PEOU) & Reflective & 4 & {$[24,25,27]$} \\
Perceived usefulness (PU) & Reflective & $30]$ \\
Perceived risk (PR) & Reflective & 5 & {$[24,25]$} \\
Perceived knowledge (PK) & Reflective & 5 & {$[24,25]$} \\
Perceived visibility of use (PVOU) & Reflective & 4 & {$[24]$} \\
\hline
\end{tabular}


Table A3. Results of SEM Analysis.

\begin{tabular}{|c|c|c|c|c|c|}
\hline Factor & Target & $\begin{array}{c}\text { Path } \\
\text { Coefficients }\end{array}$ & $t$ & Hypothesis & $\mathbf{f}^{2}$ \\
\hline ACC & IB & 0.686 & 15.364 & yes & 1.118 \\
\hline $\mathrm{ACC}$ & IU & 0.599 & 14.174 & yes & 0.572 \\
\hline PU & $\mathrm{ACC}$ & 0.507 & 8.044 & yes & 0.310 \\
\hline PEOU & ACC & 0.010 & 0.399 & no & 0.000 \\
\hline PEOU & PU & 0.187 & 3.467 & yes & 0.058 \\
\hline $\mathrm{AF}$ & ACC & 0.326 & 5.293 & yes & 0.124 \\
\hline $\mathrm{AF}$ & PEOU & 0.270 & 4.162 & yes & 0.070 \\
\hline $\mathrm{SN}$ & $\mathrm{ACC}$ & 0.051 & 1.431 & no & 0.006 \\
\hline $\mathrm{SN}$ & IMG & 0.642 & 17.497 & yes & 0.702 \\
\hline $\mathrm{SN}$ & PU & 0.283 & 5.527 & yes & 0.116 \\
\hline PI & ACC & 0.004 & 0.201 & no & 0.000 \\
\hline PI & PU & 0.019 & 0.561 & no & 0.001 \\
\hline PI & PEOU & 0.119 & 1.664 & yes (weak) & 0.017 \\
\hline PK & PU & -0.172 & 3.551 & yes (opposite sign) & 0.057 \\
\hline PK & PEOU & 0.021 & 0.458 & no & 0.001 \\
\hline EA & ACC & -0.073 & 2.073 & yes (opposite sign) & 0.020 \\
\hline EA & $\mathrm{AF}$ & -0.441 & 8.985 & yes (opposite sign) & 0.241 \\
\hline EA & $\mathrm{SN}$ & -0.296 & 4.655 & yes (opposite sign) & 0.096 \\
\hline $\mathrm{AI}$ & $\mathrm{ACC}$ & 0.026 & 0.992 & no & 0.003 \\
\hline IMG & PU & 0.027 & 0.629 & no & 0.001 \\
\hline WVN & PU & 0.136 & 2.287 & yes & 0.027 \\
\hline OQ & PU & 0.108 & 1.834 & yes (weak) & 0.021 \\
\hline $\mathrm{COMF}$ & $\mathrm{BB}$ & 0.629 & 21.135 & yes & 0.757 \\
\hline $\mathrm{BB}$ & PU & 0.234 & 3.756 & yes & 0.077 \\
\hline PR & PU & -0.107 & 2.088 & yes & 0.026 \\
\hline FCCT & PEOU & 0.067 & 1.434 & no & 0.007 \\
\hline FCCI & PEOU & 0.366 & 4.601 & yes & 0.127 \\
\hline PP & IB & 0.257 & 5.228 & yes & 0.158 \\
\hline
\end{tabular}

\section{References}

1. Federal Ministry for the Environment, Nature Conservation, Building and Nuclear Safety (BMUB). Climate Action Report 2015: The German Government's Climate Action Programme 2020; Federal Ministry for the Environment, Nature Conservation, Building and Nuclear Safety (BMUB): Bonn, Germany, 2015.

2. Federal Ministry for the Environment, Nature Conservation, Building and Nuclear Safety (BMUB). The German Government's Climate Action Programme 2020: Cabinet Decision of 3 December 2014; Federal Ministry for the Environment, Nature Conservation, Building and Nuclear Safety (BMUB): Bonn, Germany, 2014.

3. Regierungspräsidium Stuttgart. Konzept Luftreinhaltung für die Landeshauptstadt Stuttgart: Konkretisierende Stellungnahme für die Europäische Kommission; Regierungspräsidium Stuttgart: Stuttgart, Germany, 2015.

4. Bundesministerium für Wirtschaft und Energie (BMWi). Richtlinie zur Förderung des Absatzes von Elektrisch Betriebenen Fahrzeugen (Umweltbonus); Bundesministerium für Wirtschaft und Energie (BMWi): Berlin, Germany, 2016.

5. Bundesamt für Wirtschaft und Ausfuhrkontrolle (BAFA). Elektromobilität (Umweltbonus): Zwischenbilanz zum Antragstand vom 31. Mai 2017; Bundesamt für Wirtschaft und Ausfuhrkontrolle (BAFA): Eschborn, Germany, 2017.

6. Kraftfahrt Bundesamt (KBA). Fahrzeugzulassungen (FZ): Bestand an Kraftfahrzeugen nach Umwelt-Merkmalen; Kraftfahrt Bundesamt (KBA): Flensburg, Germany, 2017.

7. Kraftfahrt Bundesamt (KBA). Monatliche Neuzulassungen; Kraftfahrt Bundesamt (KBA): Flensburg, Germany, 2016.

8. Wimmelbücker, S. Keine Million Elektroautos bis 2020: Merkel verabschiedet sich vom Elektroauto-Ziel. Automobilwoche, 16 May 2017.

9. Schäuble, J.; Jochem, P.; Fichtner, W. Cross-Border Mobility for Electric Vehicles: Selected Results from One of the First Cross-Border Field Tests in Europe; KIT Scientific Publishing: Karlsruhe, Germany, 2016.

10. Muellerleile, T.; Orner, M.; Grimm, M.; Nissen, V.; Reuss, H.-C. Fully Charged: Process Acceptance of Different EV Charging Processes. SSRN 2016. [CrossRef] 
11. Taylor, M. Unplugged: Audi Readying Wireless Induction Charging for Q7 e-tron. Car and Driver. 10 April 2015. Available online: http:/ /blog.caranddriver.com/unplugged-audi-readying-wireless-induction-charging-for-q7e-tron/ (accessed on 8 June 2018).

12. Singer, M. Consumer Vehicle Technology Data; National Renewable Energy Laboratory: Golden, CO, USA, 2015.

13. BMW. BMW 5er Limousine: BMW iPerformance. Available online: https://www.bmw.de/de/ neufahrzeuge/5er/limousine/2016/iperformance.html (accessed on 8 June 2018).

14. Audi. Kleine Platte, Große Wirkung. Available online: https://www.audi.com/de/innovation/futuredrive/ wireless_charging.html (accessed on 8 June 2018).

15. Daimler. More Than Vehicles. The EQ Ecosystem. Available online: https://www.daimler.com/innovation/ case/electric/eq-ecosystem.html (accessed on 8 June 2018).

16. Schraven, S.; Kley, F.; Wietschel, M. Induktives Laden von Elektromobilen-Eine techno-ökonomische Bewertung. Z. Energiewirtschaft 2011, 35, 209-219. [CrossRef]

17. Papendick, K.; Brennecke, U.; Márquez, J.S.S.; Deml, B. Nutzerverhalten beim Laden von Elektrofahrzeugen. (de). Forsch. Innov. 2011, 10, 1-9.

18. Perik, H. CED Project Results: Feasibility Study on Inductive Wireless Vehicle Charging; Flanders DRIVE: Lommel, Belgium, 2013.

19. Frenzel, I.; Jarass, J.; Trommer, S.; Lenz, B. Erstnutzer von Elektrofahrzeugen in Deutschland: Nutzerprofile, Anschaffung, Fahrzeugnutzung; Deutsches Zentrum für Luft- und Raumfahrt e. V.: Berlin, Germany, 2015.

20. Carlson, R.W.; Normann, B. Test Results of the PLUGLESS ${ }^{\mathrm{TM}}$ Inductive Charging System from Evatran Group, Inc. SAE Int. J. Altern. Powertrains 2014, 3, 64-71. [CrossRef]

21. Weßner, K. Marktpotenziale von Induktivem Laden als Aufladetechnologie für Elektrofahrzeuge; Puls Marktforschung GmbH: Schwaig bei Nürnberg, Germany, 2011.

22. Jeong, S.; Jang, Y.J.; Kum, D. Economic Analysis of the Dynamic Charging Electric Vehicle. IEEE Trans. Power Electron. 2015, 30, 6368-6377. [CrossRef]

23. Perik, H. Practical EV Integration Cases for Static and Dynamic Wireless Power Transfer; Flanders' Drive: Lommel, Belgium, 2013.

24. Fazel, L. Akzeptanz von Elektromobilität: Entwicklung und Validierung Eines Modells Unter Berücksichtigung der Nutzungsform des Carsharing; Springer: Wiesbaden, Germany, 2014.

25. Dudenhöffer, K. Akzeptanz von Elektroautos in Deutschland und China: Eine Untersuchung von Nutzungsintentionen im Anfangsstadium der Innovationsdiffusion; Springer: Wiesbaden, Germany, 2015.

26. Davis, F.D. Perceived Usefulness, Perceived Ease of Use, and User Acceptance of Information Technology. MIS Q. 1989, 13, 319-340. [CrossRef]

27. Arndt, S. Evaluierung der Akzeptanz von Fahrerassistenzsystemen: Modell zum Kaufverhalten von Endkunden, 1st ed.; Springer: Wiesbaden, Germany, 2011.

28. Ajzen, I. The theory of planned behavior. Organ. Behav. Hum. Decis. Process. 1991, 50, 179-211. [CrossRef]

29. Homburg, C.; Klarmann, M. Die Kausalanalyse in der Empirischen Betriebswirtschaftlichen Forschung: Problemfelder und Anwendungsempfehlungen; Universität Mannheim Institut f. Marktorientierte Unternehmensführung: Mannheim, Germany, 2006.

30. Dütschke, E.; Schneider, U.; Globisch, J. Elektromobilität in Haushalten und Flotten: Was beeinflusst die Kaufund Nutzungsbereitschaft? Begleitforschung zu den Modellregionen Elektromobilität des BMVI-Ergebnisse des Themenfeldes Nutzerperspektive; Fraunhofer-Institut für System- und Innovationsforschung ISI: Karlsruhe, Germany, 2015.

31. Hair, J.F.; Ringle, C.M.; Sarstedt, M. PLS-SEM: Indeed a Silver Bullet. J. Mark. Theory Pract. 2011, 19, $139-152$. [CrossRef]

32. Herrmann, A.; Huber, F.; Kressmann, F. Varianz- und kovarianzbasierte Strukturgleichungsmodelle-Ein Leitfaden zu deren Spezifikation, Schätzung und Beurteilung. Z. Betriebswirtschaftliche Forsch. 2006, 1, $34-66$. [CrossRef]

33. Dibbern, J.; Chin, W.W. Multi-group comparison: Testing a PLS model on thesourcing of application software services across Germany and the USA using apermutation based algorithm. In Handbuch PLS-Pfadmodellierung: Methode, Anwendung, Praxisbeispiele; Bliemel, F.W., Eggert, A., Fassott, G., Henseler, J., Eds.; Schäffer-Poeschel: Stuttgart, Germany, 2005; pp. 135-160.

34. Bamberg, S.; Möser, G. Twenty years after Hines, Hungerford, and Tomera: A new meta-analysis of psycho-social determinants of pro-environmental behaviour. J. Environ. Psychol. 2007, 27, 14-25. [CrossRef] 
35. Schepers, J.; Wetzels, M. A meta-analysis of the technology acceptance model: Investigating subjective norm and moderation effects. Inf. Manag. 2007, 44, 90-103. [CrossRef]

36. Dinse, G. Akzeptanz von Wasserstoffbetriebenen Fahrzeugen: Eine Studie Über die Verwendung Eines Neuen und Ungewohnten Kraftstoffs, 5th ed.; Inst. für Mobilitätsforschung: Berlin, Germany, 2005.

37. Heffner, R.R.; Kurani, K.S.; Turrentine, T.S. Symbolism in California's early market for hybrid electric vehicles. Transp. Res. Part D Transp. Environ. 2007, 12, 396-413. [CrossRef]

38. Peters, A.; Popp, M.; Agosti, R.; Ryf, B. Electric mobility-A survey of different consumer groups in germany with regard to adoption. In Proceedings of the ECEEE Summer Study, Belambra Presqu'ile de Giens, France, 6-11 June 2011.

39. Leiner, D.J. Too Fast, Too Straight, Too Weird. Post Hoc Identification of Meaningless Data in Internet Surveys; Ludwig-Maximilians-Universität Munich: Munich, Germany, 2013.

40. Ensslen, A.; Gnann, T.; Globisch, J.; Plötz, P.; Jochem, P.; Fichtner, W. Willingness to Pay for E-Mobility Services: A Case Study from Germany. In Proceedings of the Karlsruhe Service Summit Workshop 2016, Karlsruhe, Germany, 25-26 February 2016.

41. Hulland, J. Use of partial least squares (PLS) in strategic management research: A review of four recent studies. Strat. Manag. J. 1999, 20, 195-204. [CrossRef]

42. Huber, F.; Herrmann, A.; Meyer, F.; Vogel, J.; Vollhardt, K. Kausalmodellierung Mit Partial Least Squares: Eine Anwendungsorientierte Einführung; Springer: Berlin/Heidelberg, Germany, 2008.

43. Zarantonello, L.; Pauwels-Delassus, V. The Handbook of Brand Management Scales; Routledge: London, UK, 2015.

44. DeVellis, R.F. Scale Development: Theory and Applications, 2nd ed.; SAGE Publishing: Thousand Oaks, CA, USA, 2003.

45. Bagozzi, R.P.; Yi, Y. On the evaluation of structural equation models. J. Acad. Mark. Sci. 1988, 16, 74-94. [CrossRef]

46. Fornell, C.; Larcker, D.F. Evaluating Structural Equation Models with Unobservable Variables and Measurement Error. J. Mark. Res. 1981, 18, 39-50. [CrossRef]

47. Backhaus, K.; Erichson, B.; Plinke, W.; Weiber, R. Multivariate Analysemethoden: Eine Anwendungsorientierte Einführung, 14th ed.; Springer: Berlin/Heidelberg, Germany, 2016.

48. Rossiter, J.R. The C-OAR-SE procedure for scale development in marketing. Int. J. Res. Mark. 2002, 19, 305-335. [CrossRef]

49. Jarvis, C.B.; MacKenzie, S.B.; Podsakoff, P.M. A Critical Review of Construct Indicators and Measurement Model Misspecification in Marketing and Consumer Research. J. Consum. Res. 2003, 30, 199-218. [CrossRef]

50. Fassott, G. Operationalisierung latenter Variablen in Strukturgleichungsmodellen: Eine Standortbestimmung. Z. Betriebswirtschaftliche Forsch. 2006, 58, 67-88. [CrossRef]

51. Eberl, M. Formative und Reflektive Indikatoren im Forschungsprozess: Entscheidungsregeln und die Dominanz des Reflektiven Modells; Inst. für Organisation, Seminar für Empirische Forschung und Quantitative Unternehmensplanung: München, Germany, 2004.

52. Weiber, R.; Mühlhaus, D. Strukturgleichungsmodellierung: Eine Anwendungsorientierte Einführung in die Kausalanalyse Mit Hilfe von AMOS, SmartPLS und SPSS, 2nd ed.; Springer: Berlin/Heidelberg, Germany, 2014.

53. Henseler, J.; Ringle, C.M.; Sarstedt, M. Using Partial Least Squares Path Modeling in Advertising Research: Basic Concepts and Recent Issues. In Handbook of Research on International Advertising; Okazaki, S., Ed.; Edward Elgar Publishing: Cheltenham, UK, 2012.

54. Chin, W.W. The partial least squares approach for structural equation modeling. In Methodology for Business and Management, Modern Methods for Business Research; Lawrence Erlbaum Associates Publishers: Mahwah, NJ, USA, 1998; pp. 295-336.

55. Fornell, C.; Bookstein, F.L. Two Structural Equation Models: LISREL and PLS Applied to Consumer Exit-Voice Theory. J. Mark. Res. 1982, 19, 440-452. [CrossRef]

56. Fett, D. Nutzerakzeptanz Induktiven Ladens von Elektrofahrzeugen. Master's Thesis, Institute for Industrial Production (IIP), Karlsruhe Institute of Technology, Karlsruhe, Germany, 2016.

57. Henseler, J. A new and simple approach to multi-group analysis in partial least squares path modeling. In Proceedings of the 5th International Symposium on PLS and Related Methods, Oslo, Norway, 5-7 September 2007; pp. 104-107.

58. Ensslen, A.; Jochem, P.; Rometsch, M.; Fichtner, W. Adoption of EV in the French-German context. In Cross-Border Mobility for Electric Vehicles: Selected Results from One of the First Cross-Border Field Tests 
in Europe; Schäuble, J., Jochem, P., Fichtner, W., Eds.; KIT Scientific Publishing: Karlsruhe, Germany, 2016; pp. 141-171.

59. Ketelaer, T.; Kaschub, T.; Jochem, P.; Fichtner, W. The potential of carbon dioxide emission reductions in German commercial transport by electric vehicles. Int. J. Environ. Sci. Technol. 2014, 11, 2169-2184. [CrossRef]

60. Ensslen, A.; Gnann, T.; Jochem, P.; Plötz, P.; Dütschke, E.; Fichtner, W. Can product service systems support electric vehicle adoption? Transp. Res. Part A Policy Pract. 2018, in press. [CrossRef]

61. Venkatesh, V.; Morris, M.G.; Davis, G.B.; Davis, F.D. User Acceptance of Information Technology: Toward a Unified View. MIS Q. 2003, 27, 425-478. [CrossRef]

62. Rogers, E.M. Diffusion of Innovations, 5th ed.; Free Press: New York, NY, USA, 2003.

63. Venkatesh, V.; Davis, F.D. A Theoretical Extension of the Technology Acceptance Model: Four Longitudinal Field Studies. Manag. Sci. 2000, 46, 186-204. [CrossRef]

64. Thompson, R.L.; Higgins, C.A.; Howell, J.M. Personal Computing: Toward a Conceptual Model of Utilization. MIS Q. 1991, 15, 125-143. [CrossRef]

65. Fishbein, M.; Ajzen, I. Belief, Attitude, Intention and Behavior: An Introduction to Theory and Research; Addison-Wesley: Boston, MA, USA, 1975.

66. Moore, G.C.; Benbasat, I. Development of an Instrument to Measure the Perceptions of Adopting an Information Technology Innovation. Inf. Syst. Res. 1991, 2, 192-222. [CrossRef]

67. Roberts, J.A. Profiling Levels of Socially Responsible Consumer Behavior: A Cluster Analytic Approach and Its Implications for Marketing. J. Mark. Theory Pract. 1995, 3, 97-117. [CrossRef]

68. Jabeen, F.; Olaru, D.; Smith, B.; Braunl, T.; Speidel, S. Acceptability of electric vehicles: Findings from a driver survey. In Proceedings of the Australasian Transport Research Forum, Perth, Australia, 26-29 September 2012.

69. Ensslen, A.; Jochem, P.; Fichtner, W. Experiences of EV users in the French-German context. In Proceedings of the World Electric Vehicle Symposium and Exhibition (EVS27), Barcelona, Spain, 17-20 November 2013; pp. 1-12.

70. Parasuraman, A. Technology Readiness Index (Tri): A Multiple-Item Scale to Measure Readiness to Embrace New Technologies. J. Serv. Res. 2000, 2, 307-320. [CrossRef]

71. Wietschel, M.; Dütschke, E.; Funke, S.; Peters, A.; Plötz, P. Kaufpotenzial für Elektrofahrzeuge bei Sogenannten "Early Adoptern"; Fraunhofer ISI: Karlsruhe, Germnay, 2012.

72. Manning, K.C.; Bearden, W.O.; Madden, T.J. Consumer Innovativeness and the Adoption Process. J. Consum. Psychol. 1995, 4, 329-345. [CrossRef]

73. Wippermann, C.; Calmbach, M.; Kleinhückelkotten, S. Umweltbewusstsein in Deutschland 2008: Ergebnisse Einer Repräsentativen; Bevölkerungsumfrage; Bundesministerium für Umwelt, Naturschutz, Bau und Reaktorsicherheit (BMU): Berlin, Germany, 2008. 